\title{
Sodium-dependent Net Urea Transport in Rat Initial Inner Medullary Collecting Ducts
}

Taisuke Isozaki, Janice P. Lea, James A. Tumlin, and Jeff M. Sands

Renal Division, Department of Medicine, Emory University School of Medicine, Atlanta, Georgia 30322

\begin{abstract}
We reported that feeding rats $8 \%$ protein for 3 wk induces net urea transport and morphologic changes in initial inner medullary collecting ducts (IMCDs) which are not present in rats fed $18 \%$ protein. In this study, we measured net urea transport in microperfused initial IMCDs from rats fed $8 \%$ protein for $\geq 3$ wk and tested the effect of inhibiting $\mathrm{Na}^{+}$/ $\mathrm{K}^{+}-\mathrm{ATPase}$ activity and found that adding $1 \mathrm{mM}$ ouabain to the bath reversibly inhibited net urea transport from $14 \pm 3$ to $6 \pm 2 \mathrm{pmol} / \mathrm{mm}$ per $\min (P<0.01)$, and that replacing potassium (with sodium) in the bath reversibly inhibited net urea transport from $18 \pm 3$ to $5 \pm 0 \mathrm{pmol} / \mathrm{mm}$ per min $(P<0.01)$. Replacing perfusate sodium with $N$-methyl-Dglucamine reversibly inhibited net urea transport from $12 \pm 2$ to $0 \pm 1 \mathrm{pmol} / \mathrm{mm}$ per $\min (P<0.01)$, whereas replacing bath sodium had no significant effect on net urea transport. Adding $10 \mathrm{nM}$ vasopressin to the bath exerted no significant effect on net urea transport. Finally, we measured $\mathrm{Na}^{+} / \mathrm{K}^{+}-\mathrm{ATPase}$ activity in initial and terminal IMCDs from rats fed $18 \%$ or $8 \%$ protein and found no significant difference in either subsegment. Thus, net urea transport in initial IMCDs from rats fed $8 \%$ protein for $\geq 3$ wk requires sodium in the lumen, is reduced by inhibiting $\mathrm{Na}^{+} / \mathrm{K}^{+}-$ ATPase, and is unchanged by vasopressin or phloretin. These results suggest that net urea transport may occur via a novel, secondary active, sodium-urea cotransporter. ( $J$. Clin. Invest. 1994. 94:1513-1517.) Key words: urea • inner medullary collecting duct $\bullet$ vasopressin $\bullet$ low protein diet • concentrating mechanism
\end{abstract}

\section{Introduction}

In rats fed a normal protein diet, the initial inner medullary collecting duct (IMCD) ${ }^{1}$ has a very low urea permeability that is not stimulated by vasopressin (1) or hyperosmolality (2). We have recently reported that feeding rats an $8 \%$ protein diet induces two new urea transport processes in the initial IMCD compared to findings in rats fed $18 \%$ protein (3). These changes

Address correspondence to Dr. Jeff M. Sands, Emory University School of Medicine, Renal Division, 1364 Clifton Road, NE, Atlanta, GA 30322. 1994.

Received for publication 31 March 1994 and in revised form 6 June

1. Abbreviations used in this paper: $\mathrm{IMCD}$, inner medullary collecting duct; $\mathrm{J}_{\text {urea }}$, urea flux.

J. Clin. Invest.

(c) The American Society for Clinical Investigation, Inc.

$0021-9738 / 94 / 10 / 1513 / 05 \$ 2.00$

Volume 94, October 1994, 1513-1517 in urea transport are accompanied by ultrastructural changes in principal cells located in the initial IMCD (3). Over 2 wk, the low protein diet induces a vasopressin-sensitive, phloretininhibitable, facilitated urea transport process $(3,4)$, similar to the urea transporter normally expressed in the rat terminal IMCD (1). The physiologic data suggest that this urea transporter is similar to the recently cloned vasopressin-sensitive urea transporter (5).

A second urea transport process is also induced, but only after $3 \mathrm{wk}$ of feeding $8 \%$ protein. It is a phloretin-insensitive net urea transport process $(3,4)$ and has distinct characteristics from the vasopressin-stimulated urea transporter $(3,4)$. The mechanism for this net urea flux is unknown and the major goal of the present study was to investigate whether this net urea flux is related to primary or secondary active transport.

\section{Methods}

Tissue preparation. Tubules were obtained from pathogen-free male Sprague-Dawley rats (National Cancer Institute, Frederick, MD). The rats were kept in filter-top cages with autoclaved bedding and received free access to water and either a normal $(18 \%)$ protein or a low $(8 \%)$ protein diet (NIH-31 or NIH-31M, respectively, Ziegler Brothers, Inc., Gardners, PA) for at least 3 wk. Rats fed this low protein diet grow and maintain normal values of serum albumin, creatinine, total protein, and potassium $(3,4)$.

$20 \mathrm{~min}$ before each experiment, furosemide ( $5 \mathrm{mg}$ i.p.; Astra Pharmaceutical Products, Inc., Westborough, MA) was administered (6). The kidneys were placed into chilled $\left(17^{\circ} \mathrm{C}\right)$, isotonic dissecting solution to isolate initial or terminal IMCDs as previously described $(1,3$, 4). The dissecting solution was gassed with $95 \% \mathrm{O}_{2}$ and $5 \% \mathrm{CO}_{2}$ and

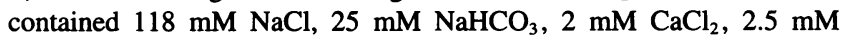
$\mathrm{K}_{2} \mathrm{HPO}_{4}, 1.2 \mathrm{mM} \mathrm{MgSO}_{4}, 5.5 \mathrm{mM}$ glucose, and $4 \mathrm{mM}$ creatinine. The tubules were transferred into a bath which was continuously exchanged and bubbled with $95 \% \mathrm{O}_{2} / 5 \% \mathrm{CO}_{2}$ gas and perfused using standard techniques $(1,3,4)$. The osmolality of all solutions was measured by vapor pressure osmometry (model 5500; Wescor, Logan, UT).

Urea measurement. The urea concentration in perfusate, bath, and collected fluid was measured using a continuous-flow ultramicro-fluorometer as previously described $(3,4,6)$. Urea flux $\left(J_{\text {urea }}\right)$ was calculated as: $J_{\text {urea }}=C_{0} V_{o}-C_{1} V_{1}$, where $C_{o}$ is the urea concentration in the perfusate, $C_{1}$ is the urea concentration in the collected fluid, $V_{o}$ is the perfusion rate per unit length of tubule, and $V_{1}$ is the collection rate per unit length of tubule.

To study net urea transport, tubules were perfused with identical perfusate and bath solution whose composition was identical to the dissection solution described above except that $3 \mathrm{mM}$ urea was added to all solutions $(3,4)$. To calculate $J_{\text {urea }}, V_{o}$ was assumed to be equal to $V_{1}$, as there was no osmotic gradient across the tubule and hence no driving force for water reabsorption, and our previous studies demonstrated that the measured water flux was 0 under these experimental conditions ( 3 ).

Effect of ouabain on net urea transport. The urea concentration of 3-4 collections was measured, after which $1 \mathrm{mM}$ ouabain (Sigma Chemical Co., St. Louis, MO) was added to the bath and 3-4 collections were obtained. Ouabain was then washed out of the bath before 3-4 additional collections were obtained. 


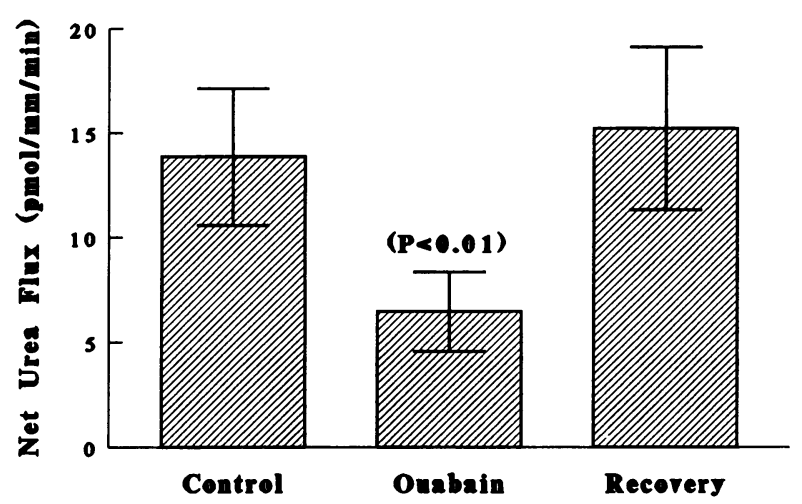

Figure 1. The effect of ouabain ( $1 \mathrm{mM}$ added to the bath) on net urea flux in initial IMCDs from rats fed $8 \%$ protein for $3 \mathrm{wk}$. Ouabain reversibly inhibited net urea flux. Net urea flux during the control and recovery phases was not statistically different. Data: mean $\pm \mathrm{SEM}, n$ $=5$.

Effect of potassium removal on net urea transport. The urea concentration of 3-4 collections was measured. After bath potassium was removed and replaced with sodium (in equimolar concentrations), 3 4 collections were obtained. Finally, potassium was returned to the bath before 3-4 additional collections were obtained.

Effect of sodium removal on net urea transport. The urea concentration of 3-4 collections was measured. Sodium was removed from either the perfusate or bath and replaced by $N$-methyl-D-glucamine (in equimolar concentrations), and 3-4 collections were obtained. Finally, sodium was returned to the perfusate or bath before 3-4 additional collections were obtained.

Effect of vasopressin on net urea transport. Phloretin $(0.25 \mathrm{mM}$, Sigma Chemical Co.) was added to the perfusate throughout the experiment to inhibit vasopressin-stimulated facilitated urea transport $(2,3$, 7). Our previous studies demonstrated that phloretin does not inhibit net urea transport (3). After 3-4 control collections, $10 \mathrm{nM}$ vasopressin (arginine vasopressin; Sigma Chemical Co.) was added to the bath and an additional 3-4 collections obtained.

Measurement of $\mathrm{Na}^{+} / \mathrm{K}^{+}-$ATPase activity. $\mathrm{Na}^{+} / \mathrm{K}^{+}$-ATPase activity was measured in initial and terminal IMCDs microdissected from collagenase-treated kidneys using previously described methods $(8,9)$. Briefly, total ATPase activity was measured by incubating tubules in the following solution (concentrations indicate final concentration in incubation solution ): $50 \mathrm{mM} \mathrm{NaCl} ; 5 \mathrm{mM} \mathrm{KCl} ; 10 \mathrm{mM} \mathrm{MgCl}_{2} ; 1 \mathrm{mM}$ EGTA; $100 \mathrm{mM}$ Tris $\mathrm{HCl} ; 10 \mathrm{mM} \mathrm{Na}{ }_{2}$ ATP (Grade II; Sigma Chemical Co.). Ouabain-insensitive ATPase activity was measured in a second group of tubules dissected from the same rat and incubated in a solution that was identical to the above except for replacement of $\mathrm{NaCl}$ and $\mathrm{KCl}$ with Tris $\mathrm{HCl}$ and addition of $1 \mathrm{mM}$ ouabain $(8,9)$. Both groups were incubated with $\gamma-\left[{ }^{32} \mathrm{P}\right]$ ATP (New England Nuclear, Boston, MA). $\mathrm{Na}^{+} / \mathrm{K}^{+}$-ATPase activity was calculated by subtracting ouabain-insensitive ATPase activity from total ATPase activity and is reported in pmol ATP hydrolyzed per $\mathrm{mm}$ tubule length per minute of incubation ( $\mathrm{pmol} / \mathrm{mm}$ per $\mathrm{min}$ ) and calculated as described previously (9).

Statistics. All data are presented as mean \pm SEM, where $n=$ number of rats. For the microperfusion experiments, data from 3-4 collections were averaged to obtain a single value from each experimental phase in each tubule. To test for statistical significance between two groups, Student's $t$ test was used. To test more than two groups, ANOVA was used, followed by a multiple-comparison, protected $t$ test $(10)$ to determine which groups were significantly different. The criterion for statistical significance was $P<0.05$.

\section{Results}

Effect of inhibiting $\mathrm{Na}^{+} / \mathrm{K}^{+}-$ATPase on net urea transport. To inhibit $\mathrm{Na}^{+} / \mathrm{K}^{+}-$ATPase activity, $1 \mathrm{mM}$ ouabain was added

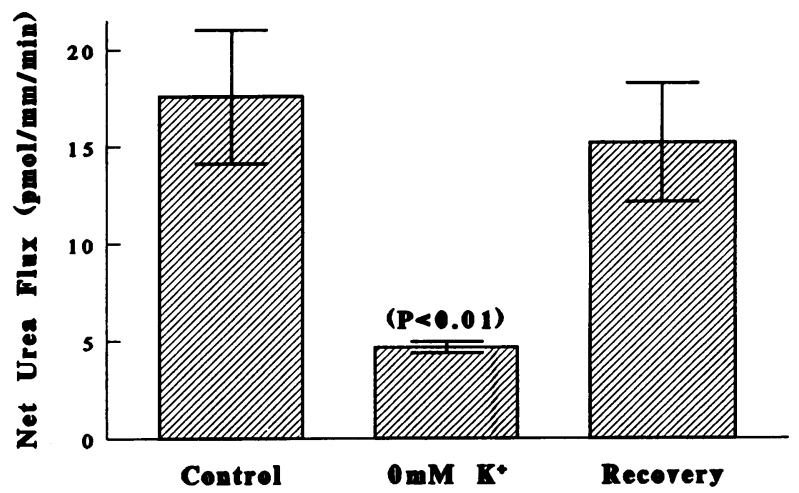

Figure 2. The effect of potassium removal (from the bath) on net urea flux in initial IMCDs from rats fed $8 \%$ protein for $3 \mathrm{wk}$. Potassium removal reversibly inhibited net urea flux. Net urea flux during the control and recovery phases was not statistically different. Data: mean $\pm \mathrm{SEM}, n=6$.

(11) to the bath and net urea flux decreased from $13.8 \pm 3.3$ to $6.5 \pm 1.9 \mathrm{pmol} / \mathrm{mm}$ per $\min (n=5, P<0.01$, Fig. 1$)$. Net urea flux returned to $15.2 \pm 3.9 \mathrm{pmol} / \mathrm{mm}$ per $\min (P=\mathrm{NS}$ vs. control, Fig. 1) when ouabain was washed out of the bath solution.

$\mathrm{Na}^{+} / \mathrm{K}^{+}-$ATPase activity was also inhibited by removing potassium from the bath solution (and replacing it with an equimolar concentration of sodium). Removing potassium from the bath reduced net urea flux from $17.6 \pm 3.4$ to $4.7 \pm 0.3 \mathrm{pmol} /$ mm per min $(n=6, P<0.01$, Fig. 2$)$. Again, net urea flux returned to $15.2 \pm 3.1 \mathrm{pmol} / \mathrm{mm}$ per $\min (n=5, P=\mathrm{NS}$ vs. control, Fig. 2) when potassium was added back to the bath solution. The percent inhibition of net urea flux by ouabain $(57 \pm 5 \%, n=5)$ and by potassium removal from the bath $(68 \pm 6 \%, n=6)$ were not statistically different.

To ensure that the reduction of net urea flux occurring when $\mathrm{Na}^{+} / \mathrm{K}^{+}-$ATPase activity was inhibited was not due to an effect of dietary protein restriction on $\mathrm{Na}^{+} / \mathrm{K}^{+}-$ATPase activity, we measured $\mathrm{Na}^{+} / \mathrm{K}^{+}-\mathrm{ATPase}$ activity in initial IMCDs and in terminal IMCDs from rats fed $18 \%$ protein or $8 \%$ protein for $3 \mathrm{wk}$. There was no significant difference between rats fed $18 \%$ or $8 \%$ protein in $\mathrm{Na}^{+} / \mathrm{K}^{+}$-ATPase activity (Fig. 3 ) or in ouabain-insensitive ATPase activity (data not shown) in either initial or terminal IMCDs.

Effect of sodium removal on net urea transport. Removing sodium from the perfusate (and replacing it with an equimolar concentration of $N$-methyl-D-glucamine) completely inhibited net urea flux from $12.5 \pm 1.3$ to $0.2 \pm 0.9 \mathrm{pmol} / \mathrm{mm}$ per $\min (n$ $=5, P<0.01$, Fig. 4). When perfusate sodium was restored, net urea flux returned to $9.8 \pm 1.6 \mathrm{pmol} / \mathrm{mm}$ per $\min (n=5, P$ $=$ NS vs. control, Fig. 4). In contrast, removing sodium from the bath (and replacing it with an equimolar concentration of $N$-methyl-D-glucamine) had no significant effect on net urea flux (control: $14.5 \pm 1.1 \mathrm{pmol} / \mathrm{mm}$ per min; bath sodium removal: $20.8 \pm 2.8 \mathrm{pmol} / \mathrm{mm}$ per min, $n=3$, Fig. 5 ).

Effect of vasopressin on net urea transport. We added phloretin $(0.25 \mathrm{mM})$ to the perfusate since our previous study (3) showed that phloretin inhibited vasopressin-stimulated facilitated urea transport but had no effect on net urea flux. The control net urea flux measured with phloretin in the lumen was $14.4 \pm 1.9 \mathrm{pmol} / \mathrm{mm}$ per $\min (n=4$, Fig. 6$)$. This value is not significantly different from the control net urea flux measured in the absence of phloretin in the preceding protocols (16.0 1.4 


\section{Rat IMCD Subsegments}

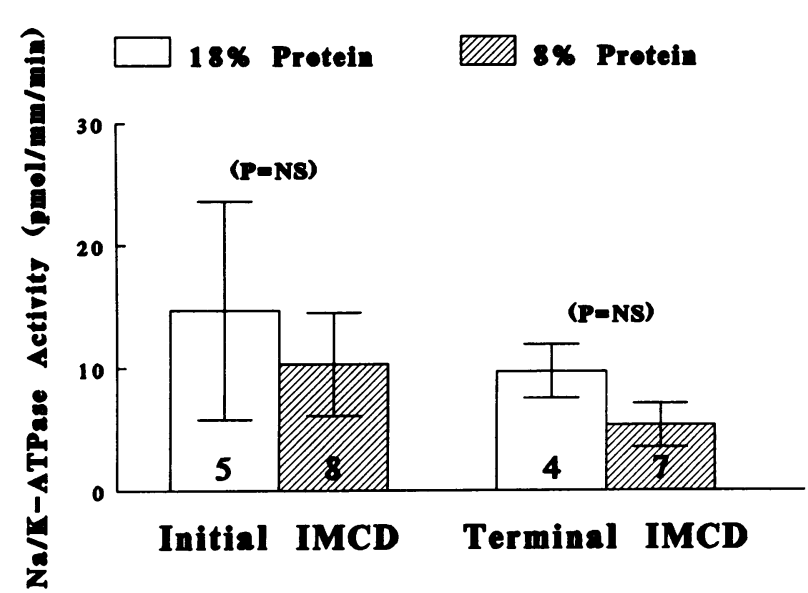

Figure $3 . \mathrm{Na}^{+} / \mathrm{K}^{+}-$ATPase activity in initial and terminal IMCDs from rats fed $18 \%$ or $8 \%$ protein diets. $\mathrm{Na}^{+} / \mathrm{K}^{+}-$ATPase activity was unchanged by dietary protein restriction in either IMCD subsegment. Open bar, NPD $=$ normal protein diet $(18 \%$ protein $)$. Hatched bar, LPD $=$ low protein diet $(8 \%$ protein $)$. Data: mean \pm SEM. The number at the bottom of each bar indicates the number of rats studied.

$\mathrm{pmol} / \mathrm{mm}$ per $\min , n=16, P=0.61)$, reconfirming that luminal phloretin does not inhibit net urea flux. Vasopressin (10 nM added to the bath) had no significant effect on net urea flux ( $16.3 \pm 1.7 \mathrm{pmol} / \mathrm{mm}$ per min, $n=4$, Fig. 6$)$.

\section{Discussion}

Our major result is that the net urea flux observed in initial IMCDs from rats fed an $8 \%$ protein diet is a secondary active urea transport process that is dependent upon sodium in the lumen. Removing luminal sodium resulted in complete inhibition of net urea transport, demonstrating that sodium in the lumen is required for net urea transport. Inhibition of $\mathrm{Na}^{+} /$ $\mathrm{K}^{+}$-ATPase activity, either by adding ouabain or removing potassium (12) from the bath significantly decreased net urea

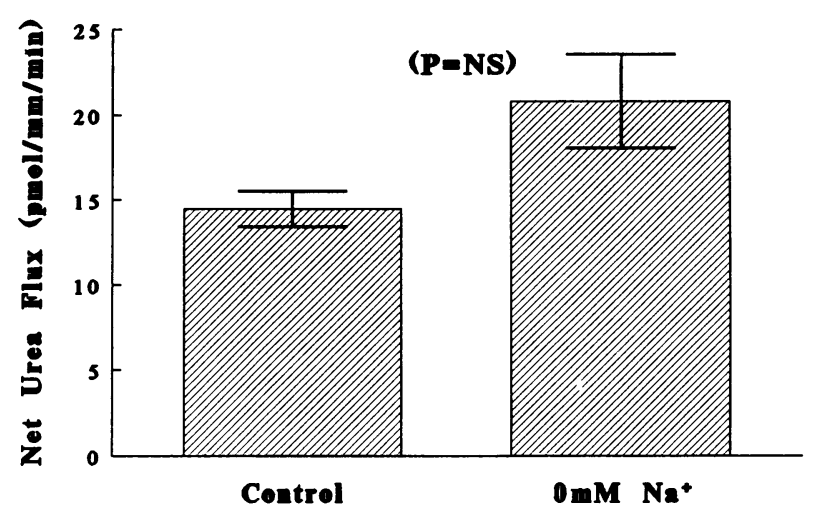

Figure 5. The effect of sodium removal from the bath on net urea flux in initial IMCDs from rats fed $8 \%$ protein for 3 wk. Bath sodium removal did not change net urea flux. Data: mean $\pm \mathrm{SEM}, n=3$.

transport, suggesting a $\mathrm{Na}^{+} / \mathrm{K}^{+}-\mathrm{ATPase}$-dependent secondary active urea transport process. Together, these results are consistent with induction of a new, sodium-urea cotransporter in initial IMCDs from rats fed an $8 \%$ protein diet for at least 3 wk. Proof of such a cotransporter will require either cloning of the cDNA or purification of the protein.

Inhibiting $\mathrm{Na}^{+} / \mathrm{K}^{+}-\mathrm{ATPase}$ activity did not inhibit net urea flux completely, as did luminal sodium removal. We speculate that the reason for this difference is that luminal sodium removal completely eliminates the lumen-to-cell sodium gradient which drives sodium-urea cotransport, while adding ouabain or removing bath potassium reduces, but may not completely eliminate, the lumen-to-cell sodium gradient.

Net urea transport. It is well known that a low protein diet reduces maximum urinary concentrating ability, reduces the fractional excretion of urea, and reverses the normal inner medullary urea concentration gradient so that the maximum inner medullary urea concentration is at the base of the inner medulla, corresponding to the location of the initial IMCD, rather than at the papillary tip (13-16). Micropuncture studies had suggested the possibility of active urea reabsorption in the collecting duct from rats fed a low protein diet $(17,18)$, but could not prove or characterize active urea transport because

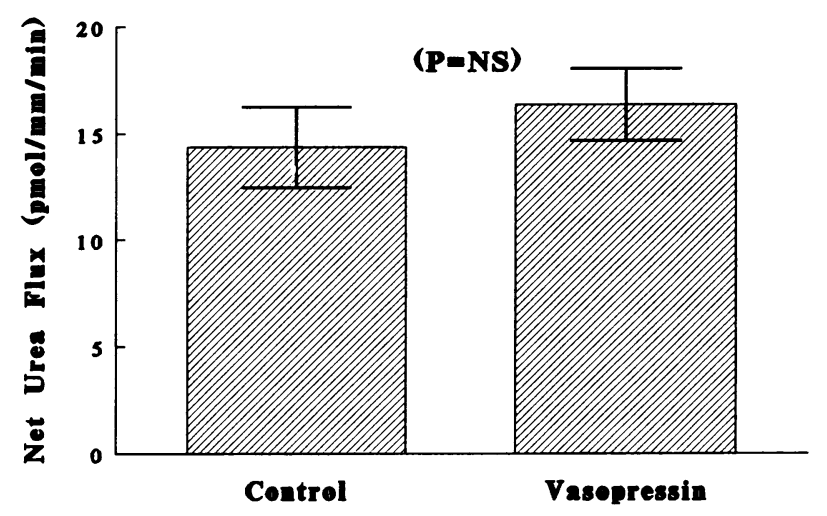

Figure 6. The effect of vasopressin ( $10 \mathrm{nM}$, added to the bath) on net urea flux in initial IMCDs from rats fed $8 \%$ protein. To inhibit vasopressin-sensitive facilitated urea transport, phloretin $(0.25 \mathrm{mM})$ was added to the lumen throughout the experiment. Vasopressin did not change net urea flux. Data: mean $\pm \mathrm{SEM}, n=4$. 
Table I. Characteristics of Active Urea Transport Processes

\begin{tabular}{|c|c|c|c|}
\hline Animal & Tissue & Characteristics & Reference \\
\hline Bufo bufo & Skin & Sodium-independent & $(23,24)$ \\
\hline Rana esculenta & Skin & Sodium-independent & $(21,24)$ \\
\hline Bufo viridis & Skin & $\begin{array}{l}\text { Sodium-independent } \\
\text { Phloretin-sensitive }\end{array}$ & $\begin{array}{l}(24) \\
(20)\end{array}$ \\
\hline Bufo marinus & Skin & Sodium-independent & (22) \\
\hline Rabbit (NZW)* & PST $^{\ddagger}$ & Phloretin-sensitive & (19) \\
\hline Rat (SD/LPD) $)^{8}$ & Initial IMCD & $\begin{array}{l}\text { Phloretin-insensitive } \\
\text { Sodium-dependent }\end{array}$ & $\begin{array}{l}\text { (3) } \\
\text { Present study }\end{array}$ \\
\hline Squalus acanthias & Renal tubule & Sodium-linked & (25) \\
\hline
\end{tabular}

Abbreviations: * NZW, New Zealand White. ${ }^{\ddagger}$ PST, proximal straight tubule. ${ }^{\S}$ SD/LPD, Sprague-Dawley fed $8 \%$ protein for $\geq 3 \mathrm{wk}$.

of the inability to measure the urea gradient across the collecting duct in vivo.

Our previous studies established that a net urea transport mechanism can be induced in the rat initial IMCD by at least 3 wk of dietary protein restriction $(3,4)$. This active urea transport mechanism was inhibited by cooling the microperfused initial IMCD to room temperature $\left(22^{\circ} \mathrm{C}\right)$ but was not inhibited by phloretin (3). However, the mechanism for this net urea flux had not been previously investigated.

The combination of sodium dependence and phloretin insensitivity differentiate this rat initial IMCD net urea transporter from all previously described active urea transport processes (19-24). Table I summarizes the characteristics of previously described active urea transport processes. The active urea transporters in the skin of Bufo bufo, Rana esculenta, Bufo viridis, and Bufo marinus are all sodium independent and/or phloretin sensitive. The active urea secretory process reported by Kawamura and Kokko (19) in rabbit proximal straight tubules was phloretin sensitive. Thus, our results with phloretin addition and with sodium removal suggest the presence of a unique transport process in initial IMCDs from rats fed a low protein diet. Our result is in agreement with a clearance study by Schmidt-Nielsen et al. (25) who reported sodium-linked urea transport in the renal tubule of the spiny dogfish Squalus acanthias (Table I). Phloretin sensitivity was not evaluated in their study (25).

You et al. recently cloned a vasopressin-stimulated, phloretin-inhibitable, sodium-independent facilitated urea transporter (UT2) from rabbit inner medulla (5). Since the expression cloning strategy employed in You et al. tested for phloretininhibitable $\left[{ }^{14} \mathrm{C}\right]$ urea uptake $(5)$, they would not have detected a second urea transporter that was phloretin insensitive. Clearly, the characteristics of UT2 are different from the properties of our net urea transporter.

We can only speculate on why two urea transport mechanisms exist in the initial IMCD. One hypothesis is based upon the difference in vasopressin sensitivity of the two transport mechanisms. The facilitated urea transporter is stimulated by vasopressin $(3,4)$ while the net urea transporter is not (present study). Thus, we propose that the induction of both urea transport mechanisms in the initial IMCD of rats fed a low protein diet would allow the rat to reabsorb urea independent of vasopressin and therefore independent of the need to reabsorb water.

$\mathrm{Na}^{+} / \mathrm{K}^{+}-$ATPase activity. Feeding rats $8 \%$ protein for $4 \mathrm{wk}$ results in a $50 \%$ increase in the basolateral plasma membrane of initial IMCD principal cells, but no change in the basolateral plasma membrane of cells in the terminal IMCD (3). We tested whether this increase in basolateral plasma membrane was associated with an increase in $\mathrm{Na}^{+} / \mathrm{K}^{+}-$ATPase activity as occurs in the cortical collecting duct following deoxycorticosterone acetate treatment $(26,27)$, but found no change in $\mathrm{Na}^{+} / \mathrm{K}^{+}$ ATPase activity in initial or terminal IMCDs from rats fed $18 \%$ or $8 \%$ protein. Our values for $\mathrm{Na}^{+} / \mathrm{K}^{+}-\mathrm{ATPase}$ activity were similar to those measured by Terada and Knepper (11) in IMCD subsegments from rats fed a normal protein diet. This result also suggests that changes in $\mathrm{Na}^{+} / \mathrm{K}^{+}$-ATPase activity are not responsible for the appearance of net urea transport in initial IMCDs from rats fed a low protein diet.

Summary. Net urea transport in initial IMCDs from rats fed $8 \%$ protein for at least $3 \mathrm{wk}$ requires sodium in the lumen, is reduced by $\mathrm{Na}^{+} / \mathrm{K}^{+}$-ATPase inhibition, is not inhibited by phloretin, and is unchanged by vasopressin. Our results suggest that net urea transport may occur via a novel, secondary active, sodium-urea cotransporter.

\section{Acknowledgments}

The authors thank Dr. William E. Mitch for his critical reading of this manuscript.

This work was supported by National Institutes of Health grant R01DK-45688. T. Isozaki performed this work during the tenure of a research fellowship from the National Kidney Foundation. J. P. Lea performed this work during the tenure of an Institutional National Research Service Award, National Institutes of Health grant T32-DK-07656. J. M. Sands performed this work during the tenure of an Established Investigatorship from the American Heart Association.

\section{References}

1. Sands, J. M., H. Nonoguchi, and M. A. Knepper. 1987. Vasopressin effects on urea and $\mathrm{H}_{2} \mathrm{O}$ transport in inner medullary collecting duct subsegments. $\mathrm{Am}$. J. Physiol. 253:F823-F832.

2. Gillin, A. G., and J. M. Sands. 1992. Characteristics of osmolarity-stimulated urea transport in the rat IMCD. Am. J. Physiol. 262:F1061-F1067.

3. Isozaki, T., J. W. Verlander, and J. M. Sands. 1993. Low protein diet alters urea transport and cell structure in rat initial inner medullary collecting duct. $J$. Clin. Invest. 92:2448-2457.

4. Isozaki, T., A. G. Gillin, C. E. Swanson, and J. M. Sands. 1994. Protein restriction sequentially induces new urea transport processes in rat initial IMCDs. Am. J. Physiol. 266:F756-F761.

5. You, G., C. P. Smith, Y. Kanai, W.-S. Lee, M. Stelzner, and M. A. Hediger. 1993. Cloning and characterization of the vasopressin-regulated urea transporter. Nature (Lond.). 365:844-847.

6. Sands, J. M., and M. A. Knepper. 1987. Urea permeability of mammalian inner medullary collecting duct system and papillary surface epithelium. J. Clin. Invest. 79:138-147.

7. Chou, C.-L., and M. A. Knepper. 1989. Inhibition of urea transport in inner medullary collecting duct by phloretin and urea analogues. Am. J. Physiol. 257:F359-F365.

8. Doucet, A., A. I. Katz, and F. Morel. 1979. Determination of Na-K-ATPase activity in single segments of the mammalian nephron. Am. J. Physiol. 237:F105F113.

9. Tumlin, J. A., and J. M. Sands. 1993. Nephron segment-specific inhibition of $\mathrm{Na}^{+} / \mathrm{K}^{+}-\mathrm{ATPase}$ activity by cyclosporin A. Kidney Int. 43:246-251.

10. Snedecor, G. W., and W. G. Cochran. 1980. Statistical Methods. Iowa State University Press, Ames, IA. 217-234.

11. Terada, Y., and M. A. Knepper. 1989. $\mathrm{Na}^{+}-\mathrm{K}^{+}$-ATPase activities in renal tubule segments of rat inner medulla. Am. J. Physiol. 256:F218-F223.

12. Kondo, Y., K. Abe, Y. Igarashi, K. Kudo, K. Tada, and K. Yoshinaga. 1993. Direct evidence for the absence of active $\mathrm{Na}^{+}$reabsorption in hamster ascending thin limb of Henle's loop. J. Clin. Invest. 91:5-11.

13. Schmidt-Nielsen, B., J. M. Barrett, B. Graves, and B. Crossley. 1985. Physiological and morphological responses of the rat kidney to reduced dietary protein. Am. J. Physiol. 248:F31-F42.

14. Truniger, B., and B. Schmidt-Nielsen. 1964. Intrarenal distribution of urea and related compounds: effect of nitrogen intake. Am. J. Physiol. 207:971-978.

15. Wilson, D. R., and H. Sonnenberg. 1982. Urea reabsorption in the medul- 
lary collecting duct of protein-depleted young rats before and after urea infusion. Pfluegers Arch. Eur. J. Physiol. 393:302-309.

16. Peil, A. E., H. Stolte, and B. Schmidt-Nielsen. 1990. Uncoupling of glomerular and tubular regulations of urea excretion in rat. Am. J. Physiol. 258:F1666-F1674.

17. Danielson, R. A., and B. Schmidt-Nielsen. 1972. Recirculation of urea analogs from renal collecting ducts of high- and low-protein-fed rats. Am. J. Physiol. 223:130-137.

18. Ullrich, K. J., G. Rumrich, and B. Schmidt-Nielsen. 1967. Urea transport in the collecting duct of rats on normal and low protein diet. Pfluegers Arch. Eur. J. Physiol. 295:147-156.

19. Kawamura, S., and J. P. Kokko. 1976. Urea secretion by the straight segment of the proximal tubule. J. Clin. Invest. 58:604-612.

20. Rapoport, J., A. Abuful, C. Chaimovitz, Z. Noeh, and R. M. Hays. 1988 Active urea transport by the skin of Bufo viridis: amiloride- and phloretin-sensitive transport sites. Am. J. Physiol. 255:F429-F433.

21. Lacoste, I., S. Dunel-Erb, B. J. Harvey, P. Laurent, and J. Ehrenfeld. 1991.
Active urea transport independent of $\mathrm{H}^{+}$and $\mathrm{Na}^{+}$transport in frog skin epithelium. Am. J. Physiol. 261:R898-R906.

22. Dytko, G., P. L. Smith, and L. B. Kinter. 1993. Urea transport in toad skin (Bu fo marinus). J. Pharmacol. Exp. Ther. 267:364-370.

23. Ussing, H., and B. Johnansen. 1969. Anomolous transport of sucrose and urea in toad skin. Nephron. 6:317-328.

24. Garcia-Romeu, F., A. Masoni, and J. Isaia. 1981. Active urea transport through isolated skins of frog and toad. Am. J. Physiol. 241:R114-R123.

25. Schmidt-Nielsen, B., B. Truniger, and L. Rabinowitz. 1972. Sodium-linked urea transport by the renal tubule of the spiny dogfish Squalus acanthias. Comp. Biochem. Physiol. A. Comp. Physiol. 42A:13-25.

26. LeHir, M., B. Kaissling, and U. C. Dubach. 1982. Distal tubular segments of the rabbit kidney after adaptation to altered $\mathrm{Na}$ - and $\mathrm{K}$-intake. II. Changes in Na-K-ATPase activity. Cell Tissue Res. 224:493-504.

27. El Mernissi, G., D. Chabardes, A. Doucet, A. Hus-Citharel, M. ImbertTeboul, F. Le Bouffant, M. Montegut, S. Siaume, and F. Morel. 1983. Changes in tubular basolateral membrane markers after chronic DOCA treatment. Am. J. Physiol. 245:F100-F109. 